\section{ASTRONOMICAL PHENOMENA FOR THE WEEK 1886 NOVEMBER 7-13}

(FOR the reckoning of time the civil day, commencing at Greenwich mean midnight, counting the hours on to 24 , is here employed.)

\section{At Greenwich on November 7}

Sun rises, 7 h. $6 \mathrm{~m}$.; souths, inh. $43 \mathrm{~m} .49^{\circ} 6 \mathrm{~s}$; ; sets, I6h. $22 \mathrm{~m}$. ; decl. on meridian, $16^{\circ} 21^{\prime}$ S. : Sidereal Time at Sunset, I $9 \mathrm{~h} .29 \mathrm{~m}$.

Moon (Full on November II) rises, I 5 h. $4 \mathrm{~m}$. ; souths, $20 \mathrm{~h} .58 \mathrm{~m}$.; sets, $3 \mathrm{~h} .2 \mathrm{~m}^{*}{ }^{*}$; decl, on meridian, $\mathrm{I}^{\circ} 49^{\prime} \mathrm{S}$.

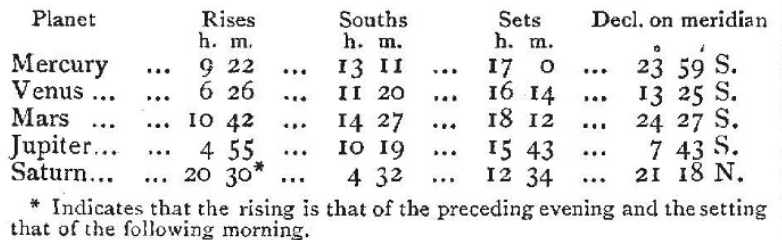
Occultations of Stars by the Moon (visible at Greenwich)

\begin{tabular}{|c|c|c|c|c|c|c|c|c|c|c|}
\hline Nov, & Star & & Mag. & & Disap. & & Reap. & & $\begin{array}{l}\text { orrest } \\
\text { igles fr } \\
x \text { to ri } \\
\text { verted }\end{array}$ & $\begin{array}{l}\text { ouding } \\
\text { rom ver } \\
\text { ight for } \\
\text { dimage }\end{array}$ \\
\hline & 4. Ceti & & & & h. m. & & $\begin{array}{l}\text { h. m. } \\
\text { Is } 32\end{array}$ & & 32 & 321 \\
\hline $\begin{array}{ll}7 & \ldots\end{array}$ & 5 Ceti & $\cdots$ & $\ldots 6$ & $\begin{array}{l}\cdots \\
\cdots\end{array}$ & 180 & $\cdots$ & $19 \begin{array}{r}52 \\
19\end{array}$ & $\begin{array}{l}\cdots \\
\cdots\end{array}$ & $\begin{array}{l}32 \\
48\end{array}$ & $\begin{array}{l}321 \\
3 \mathrm{II}\end{array}$ \\
\hline $7 \ldots$ & B.A.C. 5 & $\ldots$ & $\ldots 6$ & $\ldots$ & I8 23 & $\ldots$ & 1942 & $\ldots$ & 89 & $28 r$ \\
\hline $9 \ldots$ & $\nu$ Piscium & $1 \ldots$ & ... $4^{\frac{1}{2}}$ & $\cdots$ & 18 & $\ldots 1$ & 19 & $\cdots$ & 60 & 277 \\
\hline $12 \ldots$ & 48 Tauri & $\ldots$ & ... 6 & $\cdots$ & I9 18 & $\ldots 2$ & 2018 & $\ldots$ & $6 I$ & $25 \mathrm{I}$ \\
\hline $12 \ldots$ & $\gamma$ Tauri & $\cdots$ & .. 4 & $\cdots$ & $2 \mathrm{II} 7$ & $\ldots 2$ & $22 \quad 25$ & $\cdots$ & 55 & 27 I \\
\hline J $3 \ldots$ & 75 Tauri & $\ldots$ & .. 6 & $\ldots$ & 238 & ... & 337 & $\ldots$ & 162 & 275 \\
\hline $13 \ldots$ & $\theta^{\prime}$ Tauri & $\cdots$ & ... $4 \frac{1}{2}$ & $\ldots$ & 246 & $\ldots$ & 357 & $\ldots$ & 62 & 17 \\
\hline $13 \ldots$ & $\theta^{2}$ Tauri & $\ldots$ & ... $4^{\frac{1}{3}}$ & $\cdots$ & 6 & near & $r$ appro & ach & 39 & 一 \\
\hline 13 & B.A.C. I & $39 r$ & .. 5 & $\cdots$ & 339 & $\ldots$ & 446 & $\ldots$ & I I 5 & 332 \\
\hline$\cdots$ & Aldebar & & $\ldots I$ & $\cdots$ & 627 & $\cdots$ & 716 & $\cdots$ & 165 & 284 \\
\hline
\end{tabular}

Saturn, Nov. 7.-Outer major axis of outer ring $=43^{\prime \prime} \cdot 5$; outer minor axis of outer ring $=16^{\prime \prime} \cdot 8$; southern surface visible.

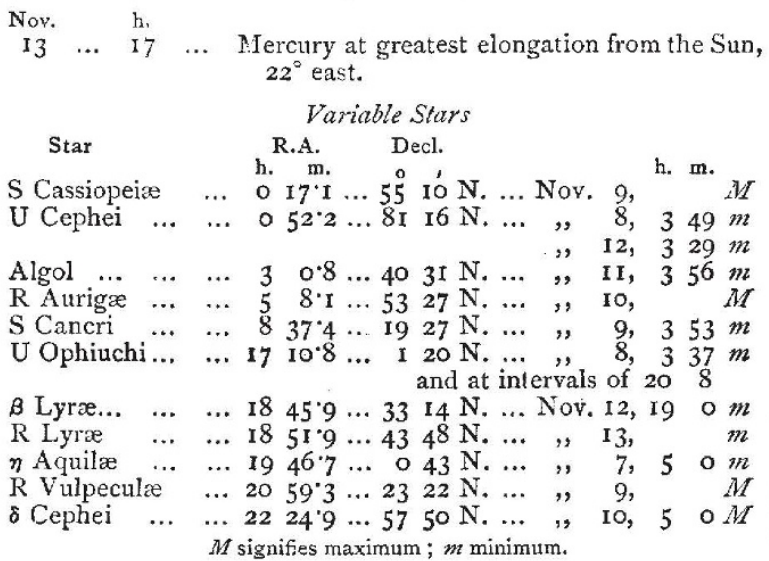
Meteor Showers

A radiant near $\delta$ Hydræ, R.A. 124. Decl. $4^{\circ}$ N., and one in Camelopardus, R.A. IO $^{\circ}$, Decl. $73^{\circ}$ N., are active in the early part of this week. Moonlight interferes with meteor observation during the greater part of the week.

\section{THE HIGH TEMPERATURE IN OCTOBER}

$T H E$ warm weather which occurred at the commencement of

the month was so exceptional for the season, and extended over so large a part of Europe, that a few facts as to its general character may be of interest, and will afford opportunity of comparison with earlier records, as well as with records of any similar weather in time to come.

The highest temperatures were experienced during the first five days of the month, and were chiefly confined to Western, Central, and Southern Europe. During this time atmospheric pressure was generally high over Central Europe, and decreased towards the western or Atlantic coasts, so that the conditions of pressure were favourable to anticyclonic circulation over France and the south-east of England, and cyclonic circulation in Ireland and the northern parts of the British Islands. The barometric gradients were very slight over the Continent, but were rather steeper over Great Britain and Ireland, owing to the proximity of a barometric depression to the westward. This distribution of pressure was accompanied by southerly and south-easterly winds over Western Europe, and especially over France and our own islands, but it was only in Ireland and the more westera parts of Great Britain that the wind was at all fresh.

At this season of the year our warmest weather in England is commonly experienced with south-easterly winds, as is well shown in the valuable discussion of the Greenwich observations for the years 1849 to 1868 , in which the temperatures have been averaged for the several wind directions. The following are the temperatures for October :-

$\begin{array}{ccccccccc}\text { Monthly means } & \text { N. } & \text { N.E. } & \text { E. } & \text { S.E. } & \text { S. } & \text { S.W. } & \text { W. } & \text { N.W } \\ \left.\begin{array}{c}\text { Highest hourly } \\ \text { means }\end{array}\right\} & 50 & 52 & 55 & 53 & 53 & 5 \mathrm{t} & 5 \mathrm{I} \\ & 52 & 55 & 59 & 6 \mathrm{I} & 59 & 5^{8} & 57 & 55\end{array}$

The same discussion also shows the striking difference which exists, in October, between the temperature with a clondless and a cloudy sky :-

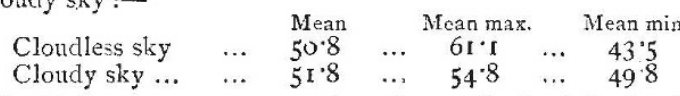

The high temperatures experienced over England in October this year occurred with an exceptionally clear sky, as well as with a remarkably steady south-easterly wind, and the air before reaching England had been subjected to very similar conditions on the continent of Europe.

The following table gives the maximum day temperatures at twenty stations selected from the Daily Weather Report of the Meteorological Office and from the Paris Bulletin Inter nation.ut for the first five days of October :-

\begin{tabular}{|c|c|c|c|c|c|c|c|c|c|}
\hline & Station & & & $y x$ & 2 & 3 & & 5 & $M=$ \\
\hline & York. & & $\cdots$ & 64 & 63 & 66 & 69 & 63 & \\
\hline & Greenwich & & & $7^{8}$ & 68 & 69 & 79 & 77 & \\
\hline & town! & Irela & nd) & $5^{8}$ & 61 & 61 & 64 & & \\
\hline & $\ldots$ & $\ldots$ & $\ldots$ & 79 & 72 & 72 & I & 79 & 7 \\
\hline & urg & $\ldots$ & $\ldots$ & 72 & 73 & 01 & 2 & 68 & \\
\hline France & $\ldots$ & $\ldots$ & $\ldots$ & 77 & 65 & 78 & 78 & 77 & \\
\hline & $\ldots$ & $\ldots$ & $\ldots$ & 7 & 70 & $8 \mathbf{I}$ & 2 & $6+$ & \\
\hline & $\begin{array}{ll}\mathrm{tz} & \ldots\end{array}$ & $\ldots$ & $\ldots$ & 82 & 73 & $8 I$ & I & 68 & 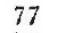 \\
\hline & $\ldots$ & $\cdots$ & $\ldots$ & 72 & 3 & 75 & 77 & 75 & \\
\hline & $\operatorname{urg} . .$. & & $\ldots$ & $6 I$ & 3 & I & 64 & 68 & 01 \\
\hline ermany & $\mathrm{Be}$ & $\ldots$ & $\ldots$ & 63 & 3 & 63 & $6 r$ & 66 & 65 \\
\hline & he... & $\ldots$ & $\ldots$ & 75 & 70 & 75 & 72 & 70 & $7^{2}$ \\
\hline Belg & ls $\ldots$ & $\ldots$ & $\ldots$ & 76 & 64 & 71 & 5 & 77 & \\
\hline & $\ldots$ & $\ldots$ & $\ldots$ & 73 & 75 & 73 & 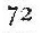 & 70 & 7. \\
\hline S & na... & $\ldots$ & $\ldots$ & 85 & 100 & & I & 85 & \\
\hline & & $\ldots$ & $\ldots$ & 62 & 72 & 7 & 70 & 68? & 69 \\
\hline ortugal & $\ldots$ & $\ldots$ & $\ldots$ & 70 & 68 & 68 & 70 & 68 & 6 \\
\hline & & $\ldots$ & $\cdots$ & 72 & 73 & 73 & 3 & 73 & \\
\hline Italy & & & & & 79 & ox & I & $8 \mathrm{r}$ & \\
\hline & (Si & & $\cdots$ & & & 84 & 2 & 84 & \\
\hline & & & & 3 & & 3 & 75 & 72 & \\
\hline
\end{tabular}

The stations have been selected as representative of Western, Central, and Southern Europe, and the table shows well the area over which the warm weather extended.

The more northern parts of Europe did not experience any exceptional heat, the highest temperature at Copenhagen being $63^{\circ}$, and at Stockholm $6 \mathrm{r}^{\circ}$. The more western parts were also but little affected : in Ireland the highest maximum was $66^{\circ}$ at Parsonstown on the 5th, and at no other station was the temperature above $65^{\circ}$. In Scotland the temperature did not rear' $70^{\circ}$.

The Greenwich observations from $184 \mathrm{I}$ show that a higher temperature has only once been registered in October, viz. $8 \mathbf{r}^{\circ}$ on the $4^{\text {th }}$ in 1859 ; but the daily mean, which was $67^{\circ} .1$ on the $4^{\text {th }}$ this year, is hi gher than any previously recorded.

The observations which were made in the apartments of the Royal Society from the year I794, excepting the years I8I I to I8r9, do not show so high a reading between I794 and I840. At Kew Observatory the highest temperature recorded was $77^{\circ}$ 